\title{
Residential Electric Load Curve Modelling Via BEopt
}

\author{
amira attia ${ }^{1}$
}

${ }^{1}$ Alexandria Higher Institute of Engineering and Technology

June 18, 2020

\begin{abstract}
Availability of load profile data is essential for studying and assessing different demand side management programs especially in residential loads. To build residential load curve a lot of data are required such as habitant's daily activities, sort of appliances he owns and their hourly profile. Depending on availability of data, a different methods were introduced to construct load curve. There are three approaches for building load curve; top-down approach, bottom-up approach and hybrid approach. In this paper, steps on how to use each approach to build load curve are briefly reviewed. Bottom-up approach is the most common method used for load profile estimation. However due to lack of availability of required data, different software is introduced depending on type of load used; commercial or residential with built in data necessary for load profile conduction in short time. Building Energy Optimization (BEopt) software is used to give hourly consumption curve in residential sector. BEopt software is expounded as a full packaged software that can be used by customer or researcher to understand load curve for each residential unit and for the whole building. And to study the effect of both appliances and home texture on energy consumption result as well.
\end{abstract}

\section{Hosted file}

load profiling.pdf available at https://authorea.com/users/334845/articles/460768residential-electric-load-curve-modelling-via-beopt 